Štefan Rehák, Bratislava / Oto Hudec, Košice / Milan Buček, Bratislava

\title{
Path dependency and path plasticity in emerging industries
}

Two cases from Slovakia

\begin{abstract}
The article is focused on the evolution of emerging industries based on the concepts of path dependency, path creation and path plasticity. Based on an analysis of the evolution of the IT sector in two regions of Slovakia - Bratislava and Košice - it explores to what extent was the emergence of new industries influenced by the former industrial mix and the formal and informal institutions established in the preceding periods.
\end{abstract}

Keywords: path plasticity, emerging industries, Slovakia, IT sector

\section{Introduction}

Countries in Central and Eastern Europe are characterized by low innovation performance, which is the result of rigid and fragmented innovation systems (DYKER 1997; DYKER/ RADOSEVIC 2000; PIECH 2007). The concept of evolutionary economic geography (BoschMA/ FRENKEN 2006) follows the empirics of case studies which describe the evolution of industries in the institutional framework of developed economies (for an overview BosCHMA/FrENKEN 2011). Research on new industries in the postsocialist economies can contribute with critical evaluation and question the general validity of concepts of regional innovation. Economic and institutional changes in a relatively short period of time provide ample research opportunities based on evolutionary geographical approaches as the behaviour of firms and entire industries was visibly changing over time.

This article aims to analyse the evolution of the IT sector in two regions of Slovakia based on the concepts of evolutionary economic geography. Economic transformation induced industrial restructuring by enabling new knowledge combinations detached from the previous institutional system. The question is to what extent the emergence of new industries was influenced by the former industrial mix and the formal and informal institutions established in the preceding periods. The article intends to question which factors determine path dependency or plasticity of the development. It aims to contri- bute to the on-going debate of the mechanisms of regional structural changes from the evolutionary economic geography approach. The key to unlock these mechanisms lies in the understanding of knowledge-related processes, which accompany the emergence and growth of new industries.

Economic development in the country was affected by two major changes. The first major change was the transformation of the economy from a centrally planned to a market economy in the early 1990s. The economic transition brought the reorganisation of the enterprise sector and formed new industrial structures with new boundaries of firms. Another important change was the significant economic reforms in the years 2002 to 2006 (introduction of the flat tax, social welfare system reform, labour market reforms) and it is related to joining the EU and NATO in 2004. These changes significantly affected the image of the Slovak Republic (SR) for investors, encouraged mobility of capital, labour and knowledge. Changes in the business environment at the same time initiated the growth of entrepreneurship in the economy.

In the following, first, the evolution of emerging industries from the concepts of path dependency, path creation and path plasticity is discussed. Secondly, two case studies exploring the evolution of the IT sector in the Bratislava and Košice regions are presented. In the final part, the implications of the empirical research are further discussed. 


\section{Emerging industries in concepts of path dependency, path creation and path plasticity}

The concept of path dependence mostly applies to the explanation of persistent industrial specialisation and success and to the problems of slow restructuring and modernisation of old industrial regions (GRABHER 1993; HUDSON 2005; Hodson 2008; TRIPPLe/TodTLING 2008). The corresponding regional lock-in is a result of technology (DAVID 1985) and institutional path dependence (NORTH 1990). The sequence of events creates a self-reinforcing mechanism that seeds structures stabilising existing development path (MARTIN/SUNLEY 2006). Co-evolution of institutions and firms supports cumulative knowledge dynamics, strengthens the existing development path and hampers the radical changes (NORTH 2003). The institutional path dependency therefore comes from positive network externalities and economies of scale arising from the existing institutional arrangements. Accordingly, any deviation from the established practices most likely will not survive. The whole process has been described by so-called territorial innovation models (MOULAERT/SEKIA 2003). Concepts such as regional innovation systems (BRACZYK/COOKE/HEIDENREICH 1998), learning region (MORGAN 1997, Florida 1995), innovative clusters (PORTER 1990); innovative milieu (CAmagni/Maillat ed. 2006) or industrial districts (PIORE/SABEL 1984) focus on exploring the continuity and cumulating of the knowledge processes, emphasizing the role of spatial proximity for localized learning and knowledge externalities. Knowledge is generated in a cumulative way (ANTONELLI 2008); it means that generation of new knowledge builds upon existing knowledge. Based on the AsHeIM et al. (2007) SAS (= synthetic, analytical and symbolic) taxonomy of knowledge bases, we can distinguish between three ways of creating knowledge. Analytic knowledge generation involves the application of scientific principles and methods; synthetic knowledge generation forms new knowledge mainly by new combinations of existing knowledge to construct practical solutions, and finally symbolic knowledge is created by creative thinking showing new ways of interpreting established conventions. Cumulative dynamics cause continuity of stability of routines and other institutions which lead knowledge generation. A number of empirical studies of the evolution of industrial clusters from the automotive sector (KLEPPER 2002a, 2002b), the semiconductor industry (SAXENIAN 1994), or the rubber industry (BUENSTORF/KLEPPER 2009) explain the main ingredients of industrial changes, as well as the spatial aspects. Spin-off processes are considered to be the key mechanism for the creation and development of new clusters (ARTHUR 1994; KLEPPER 2010). Those processes represent the creation of new firms, which detach from parent companies. Location spin-off companies follow the location of the parent companies, contributing in this way to deepening and stabilising the spatial distribution of industries over time. The establishment of a small number of firms in a particular location at the beginning results in a number of spin-off companies at later stages, which deepen the degree of industry concentration. Increasing concentrations of firms in the region indicates the appropriate location for future business conditions; thereby further deepening concentration (SUIRE/VicENTE 2009). ViCENTE/ SUIRE (2007) stressing the role of social interactions in the location decisions of firms leading to the mimetic behaviour, i. e. in the convergence of choices of location of similar firms. Under the uncertainty, firms tend to confront their individual expectations with the collective choice of other firms (Vicente/Suire 2007, 176). Spatial clustering is clearly a path dependent process from such a viewpoint. In addition, strong interactions among clustered firms contribute to reach network externalities which stabilise the spatial system. Local spin-off processes enhance transfer of organisational routines and technological and managerial knowledge, acquired by the workers in the former firms. A growing number of firms in a region contribute to higher competition and rivalry (PORTER 1990), which may either lead to termination of the less successful companies or to their departure. The proximity of firms in the same industry leads commonly to increasing returns arising from agglomeration economies. The higher the number of located firms in the same industry in the region, the higher externalities in the form of knowledge spill-over could be acquired.

Rather deterministic perspectives of the concept on industrial development have been widely discussed and attention focused towards the processes which lead to the creation of new paths. Traditionally, the authors have not explained the circumstances and processes which could lead to a new industrial trajectory (ARTHUR 1994; Krugman 1991). As Martin/Simmie (2008) and MARTIN/SUNLEY (2006) commented, novelty and the emergence of new pathways is considered to 
be serendipitous. The concept of path creation (GRAUD/KARNøE 2001) offers an alternative explanation focusing on the role of heroic entrepreneurs that deviate from the existing structures and provide a way of understanding how to escape lock-ins. GRAUD/KARNøE (2001) have criticized the path dependency concept as looking too much to the history, just describing the past but not offering solutions for the development of future possibilities. The emergence of major innovations is accompanied by radically new combinations of knowledge and because of this it is unlikely that new firms will be compatible with the existing institutional environment. It is exactly the opposite; it is likely that the existing routines and institutions hamper the birth of new industries. Radical innovations lead instead to a self-enforcing creative destruction process which breaks down the established institutional setting and replaces it with a new one. Therefore, new firms in emerging industries do not draw on existing institutional conditions but they create their own institutional setting. The geography of the location of new firms has been described by SCOTT/STORPER (1987) and further extended by BOSCHMA / VAN DER KNAPP (1999) as the concept of the window of locational opportunity (WLO). The concept was applied to answer the question whether new industries will disrupt an established spatial system. As new industry does not draw on local conditions in order to support its growth, each region has the same chance for the location of the industry. Although the spatial arrangement of new industries is uncertain and emerging industries do not have specific location preferences, regional conditions such as knowledge, skills, infrastructure and openness may play generic roles at the start of the sector (BOSCHMA/FrENKEN 2006).

In the well-established development path institutions support continuity rather than novelty and breakthrough. But is there room for manœuvre for emerging industries without breaking the established path? The concept of path plasticity (STRAMBACH 2010) aims to capture the institutional dynamics within path dependent processes. It is believed that growth impulses come from new combinations of knowledge crossing boundaries of sectors and regions. The concepts of absorptive capacity (COHEN/ LEVINTHAL 1990), local buzz and global pipelines (BAthelt/Malmberg/Maskell 2004) or territorial knowledge dynamics (CREviOSIER/ JEANNERAT 2009) uncover the role of external knowledge. Especially for firms in emerging industries it is less likely that they will find the necessary knowledge in local networks. The study of Vale/CARVAlHo (2012) exposed that distant knowledge interactions were shown to be important at the emergence and early growth of the Portuguese biotechnology industry. A number of other studies emphasized a growing role of distant learning for the development of new industries (FAUlCONBRIDGE 2006; STRAMBACH 2008; TRIPPLE/TODTLING/LENGAUER 2009; SOTARAUTA et al. 2011). External knowledge could bring novel ways of interpretation of local knowledge and create new value. At the same time non-local interactions help to overcome the lock-in problems and increase the ability to adapt to the technological or market changes. Innovation activities of firms are currently becoming increasingly multi-local and multi-scalar, which is a result of increasing mobility of both tacit and codified knowledge. Interactions of mobile knowledge with local knowledge pools include appropriation and contextualisation of mobile knowledge, i.e. knowledge anchoring (CREVIOSIER/JEANNERAT 2009; DAHLSTRÖM/JAMES 2012). Policies should aim more at supporting extra regional relations, the development of anchoring capacity or linking intra with extra regional networks (DAHLSTRÖM/JAMES 2012). The concept of knowledge dynamics focuses on the transformation of knowledge as one of the driving forces of innovation (STRAMBACH/ KLEMENT 2012) and uncovers the complex social dynamics behind the production of knowledge. Research on knowledge dynamics explores the role of combinatorial dynamics, i. e. innovation based on the combination of different knowledge bases. Microdynamics of innovation processes showed that firms interact also across separated but interconnected knowledge bases (Maninche 2012; Strambach/Klement 2012). Within such constellation it is difficult for firms to develop routines, especially when the cognitive distance is large. Firms from different knowledge backgrounds have to cope with the incompatibility of organisational, technological and institutional differences and must invest in establishing mutual understanding (STRAMBACH/ KLEMENT 2012).

There is a conflict between the concept of path dependency and the emergence of new industries. STORZ (2009) proposes that if we want to understand the emergence of new industries, it is important to combine the concepts of path dependency and path plasticity. In addition, there is an open question of the relation between the 
old industries and emerging industries. As DAHL (2011) showed, the first generation companies are the spin-off companies, usually established by entrepreneurs previously employed by the old industries. New knowledge pools are being formed as a mixture of knowledge inherited from the previous periods in related industries together with new vintages of specialised knowledge. Emerging industries can be found therefore in cognitive fields (NотевоOM 2002) closely related to dominant regional industries (FRENKEN et al. 2007). Emerging industries in the region are represented only by a small group of firms which do not benefit from localisation economies such as a major labour market, specialised services or knowledge spillovers (Boschma/Wenting 2007). However, they benefit from the availability of skilled labour, capital and infrastructure in related industries, especially in urban regions. Urbanisation economies dominate over localisation economies. Spatial proximity allows a more intensive and frequent interaction of agents, inter-firm learning and tacit knowledge transfer. From the perspective of combinatorial knowledge dynamics identification of perspective groups of related industries which could bring a variety of new combinations of ideas without investing too much in the reconstruction of the whole institutional system.

\section{Rationale of the case studies selection and methodology}

The IT sector ${ }^{1}$ is one of the most dynamic industries in Slovakia which demonstrated substantial growth dynamics, especially during 2002-2008. It is one of the few industries which produces innovative firms with products successful on a global scale. The empirical part of the article describes the emergence and development of the IT sector in the Bratislava and Košice regions. These two regions account together for $80 \%$ of employment in the sector and $44 \%$ of the number of IT firms (2008). At the beginning of the 1990s both regions had approximately comparable levels of employment in IT. In 1997, the share of employment in the IT sector was around $35 \%$ in the Bratislava region and $21 \%$ in the Košice region. Even given that both regions faced the same institutional changes, the development of the IT sector was significantly different. In 2008, the market share of the Bratislava region was $62 \%$, whilst the Košice region had dropped to $18 \%$. While the growth of employment in the IT sector in the Bratislava region was stable, the Košice region recorded a decline until 2003. After 2004, both regions experienced significant growth in employment. Employment in the Bratislava region had increased 2.2 times, but in the Košice region it was higher at 3.8 times. These figures imply important structural changes in the sector and our research tried to identify the factors that enabled and influenced the changes in the development path. While the Bratislava region has developed into a region with a diverse economic base, with greater focus on services, the Kosice region is strongly dominated by heavy industries.

The article draws from the research undertaken within the EURODITE project which was further extended in Slovakia by the project REDIPE. $^{2}$ The research was based on the desk research and a series of in-depth interviews between 2008-2011, with the key representatives of the IT sector - firms, associations, universities and research centres, knowledge intermediaries, and local policy makers. In total, we had more than 50 interviews with a group of firms which had been established in the early 1990s and firms established after 2004. The selection of firms was based on their relevance to the economy, size and innovation. Each interview was recorded and the transcript of report from the interview was checked with the respondent.

\section{Origins and evolution of the IT sector in the Bratislava and Košice regions}

\section{Brief description of the case study regions}

The Bratislava region is the most economically developed region in the Slovak economy with a $26 \%$ share of gross domestic product (2007) and a consistently low rate of unemployment. From the region dominated by large manufacturing firms in the early 1990s it has developed into a diversified region with a large tertiary sector. On-going structural changes in the regional economy resulted in a growing importance of the services, particularly in trade, finance and insurance. Manufacturing still plays an important role in the region, as the region developed into a centre of automotive industry of European importance (Volkswagen). The IT sector was, during 1997 to 2008, the fastest growing industry in the Bratislava region. Employment increased more than five times from 1563 (1997) to 8075 (2008). Currently, the industry is the largest employer in the region. 
Fig. 1: The development of the IT sector (NACE 72) in the Bratislava and Košice regions (1997-2008)

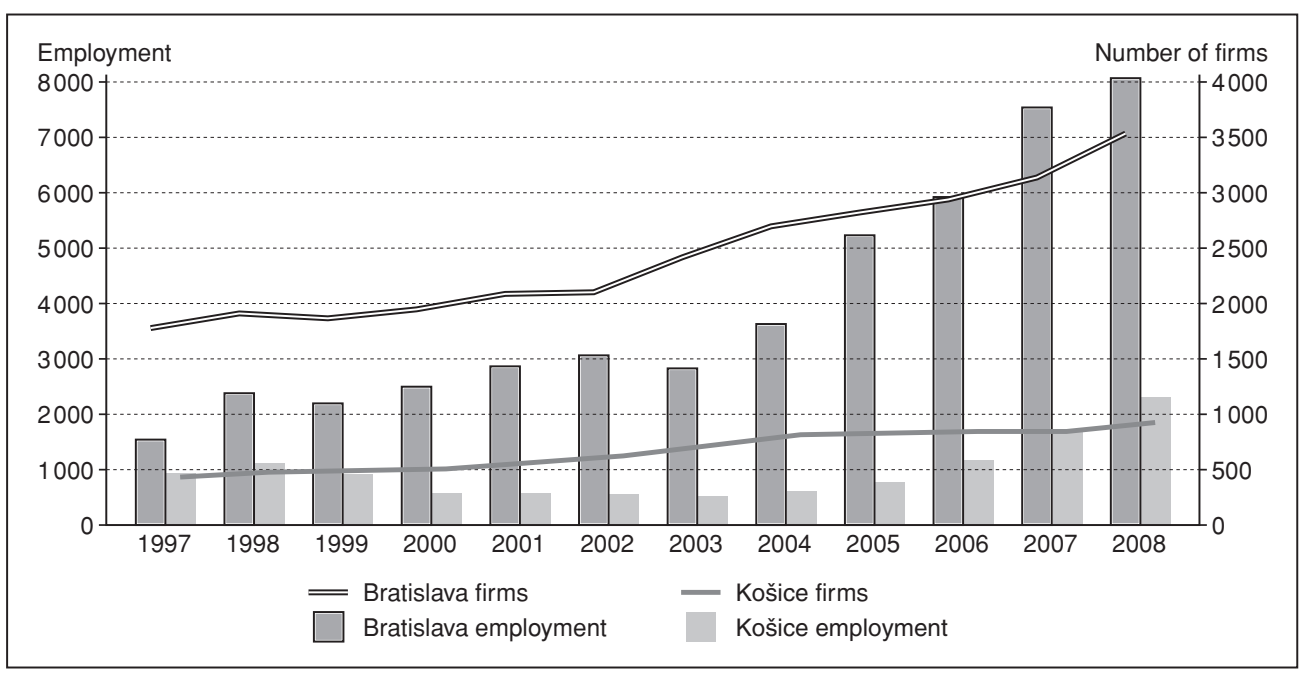

Source: own elaboration, data from the databases of Statistical Office of Slovak Republic and Infostat (SR)

The Košice region has, for a long time, been dominated by the metallurgy sector (with more than 13000 employees) and transportation (14000 employees). The Košice region could be labelled as an industrial region dominated by traditional "old" industries exhibiting a lack of further technologically advanced sectors. This is an apparent heritage of the former centrally planned economy, when the industrial tradition has been injected quite recently (1945-1960). In the first decade of the 21st century a coexistence of traditional (manufacturing) and new (IT cluster) industries can be seen. The increase in employment after 2004 was mainly associated with the opening of branches of major international IT companies.

\section{Evolution of the IT sector in the Bratislava region}

Origins and emergence of the IT sector in the Bratislava region (up to 2003): The location of the IT sector in the Bratislava region has been influenced by three significant factors. First, the establishment of the first IT companies in the early 1990s was the result of 20 years of accumulation of human capital in the academic sector and specialised computing centres of the former state companies. The development was based on the accumulation of knowledge in cybernetics, software development and computer systems. Its history dates back to the middle of the 20th century, when the Institute of Technical Cybernetics began to develop the first software. Later, in 1967, a computing research centre was established based on the UN initiative. The centre became the prominent software organisation in Slovakia. Another milestone of new IT skills development was the creation of the Department of Mathematical Machines at the Slovak University of Technology and the Department of Computer Science at the Comenius University (1973). The development of the IT knowledge base in the business sector was linked to the computerisation in the medium and large state-owned companies and major government offices. Despite this the establishment of computer centres in large firms was largely spontaneous and uncoordinated, several large and at that time very progressive IT systems were developed (e.g. process control software in Slovnaft or medical expert system CODEX). Although information technologies before 1989 addressed only a narrow group of people, dissemination of knowledge in the region was carried out through seminars and computer clubs. Those structures, unifying IT enthusiasts as well as professionals, served as the main platform for the knowledge interchange.

The subsequent impetus has come from the transition from central planning to the market economy since the early 1990s. The establishment of IT companies in the first half of the 1990 s was as- 
sociated with the break-up of the academic sector and the outflow of academics from the sector. Changes in the economic system resulted in the new commercial structure. The large state companies were privatised, broken up into smaller firms. Several current major IT companies such as Datalock (Asseco nowadays) or PosAm were created as spin-offs of the state companies by their former employees. The academic sector significantly reduced its size and a number of organisations were abolished. Experts working in the academic sector moved to the commercial sphere, or they set up their own businesses. Large local companies such as Tronet (currently Soitron), Softec, Datalan or Ditec have their roots in the academic sphere. The second wave of university spin-offs emerged later, after 2002, as the result of a transformation process at the universities and a boom in the economy.

IT industry development was mainly driven by the technological backwardness of customers. Newly established firms in that period started mainly with selling hardware or software, although often evolving to software development and system solutions. However, the software industry was hampered by a lack of experts in that period. The two main faculties that provided training in the IT sector were located in the Bratislava region (the Faculty of Electrical Engineering at the Slovak University of Technology, and the Faculty of Mathematics and Physics at Comenius University) faced a reduction in the number of applicants. Conversely, the growth in the number of students in the nontechnical disciplines focused mainly on the Faculty of Business Informatics at the University of Economics. New courses had been established at the universities; however a minimum of them came as a requirement of business, as with most of the activity of lecturers. A major milestone in the process of curriculum restructuring was the establishment of the Faculty of Informatics and Information Technologies (FIIT) at the Slovak University of Technology in Bratislava in 2003. A low level of cooperation with IT companies in the IT education reform led to criticism of the quality of universities by companies and associations. To promote knowledge transfer, the Know-how Centre (2000) and the University Technology Incubator InQB (2003) were established.

The first efforts to institutionalise the emerging industry date back to the early 1990s. The Electronics Industry Association was founded in 1991 and the first academic association, the Slovak Academic Association of Computer Society, in 1993. Both associations formed the basic framework of the IT sector institutionalisation but at that time their position was weak, formal and based predominately on domestic firms. The establishment of IT Association Slovakia (ITAS) in 1999 marked the first step towards a greater cooperation of companies. The increasing specialisation of the industry was initiated founding specialised associations such as Slovak Association for Information Security (SASIB) and Slovak Association for Electronic Commerce (SEAC). Interestingly, none of these associations had a local focus. The associations intensively developed their activities by organising conferences, exhibitions, and educational activities, and participated in policy forming. National IT associations became members of international associations and began to participate in international projects, or international conferences. In this way the non-local knowledge is anchored and a better spread of local knowledge is achieved.

The third impulse of the IT industry development in the Bratislava region was due to foreign IT investment. The development centres of the global IT companies such as Hewlett-Packard and Siemens were established in the early nineties. In addition, Microsoft (1995), SAS (1995) and $S A P$ (1993) established their business units to support the distribution of their products. The representatives of IT companies pointed to benefits of the Bratislava region, which included the availability of skilled workers, high-quality telecommunication infrastructure, the presence of universities and an easy transportation access via Vienna. Political changes, economic reforms, deregulation and progress in the economy as well as liberalisation during the transition period have promoted the growth of investment in the IT sector. The progress resulted in the employment growth that roughly doubled the IT employment (up to 2003, 643 companies were established in Bratislava). The extensive growth of the IT sector was accompanied by the increasing specialisation of the firms. Since the margin of hardware sales declined, many IT companies were forced to concentrate on software development (PÁsTOR 2012). Also, new niche markets in information security (Gordias in 1997) or e-business (Millennium 000 in 1998) emerged. After 2002 branches of global IT companies expanded local capacities and competences. At the same time, the next wave of branches of large 
multinational companies (e.g. IBM, Dell, Accenture, Lenovo) and Czech IT companies (e.g. Unicorn, Cigler Software) had been set up. Since 2000 , virtually all major global IT players were present in the region. Domestic firms in the IT sector expanded their services, invested both in the skills development and new technologies. Knowledge creation in that period remained almost strictly intra-firm. Large multinational firms created internal channels through which they were able to transfer non-local knowledge. Local IT firms faced fierce competition from the multinationals in the labour market. Growing inter-firm mobility and insufficient labour market flexibility resulted in a rapid growth of salaries in the sector.

Global expansion (post 2004): The EU accession and economic reforms before 2004 supported industry investments and growth. Over 5000 new jobs and 1000 new firms have been created. Employment growth was mainly associated with the emergence of call centres and the development centres of foreign investors. In 2006 the Accenture, Dell, HP, IBM, Lenovo service centres had created more than 1000 working places. The main drivers of the increase in turnover in the IT industry in recent years were the demands from the mobile operators, banks and the Euro conversion. Growth in the IT sector today has been also largely supported by the projects in the field of public administration (e-government).

A group of so-called born global companies such as Ardaco (2006) in the security of mobile communications, Innovatrics (2004) in biometrics, Sygic (2004) in navigation software, or mSolutions in mobile marketing (2006), document the expansion of innovative solutions. Some of the most innovative firms belong to the fastest growing IT companies in the world rankings, such as Deloitte EMEA Fast 50. The growing strength of companies induced a number of acquisitions not only in Slovakia but also outside her borders. The process started with the acquisitions of Tempest in the years 2004-2006 (Protect eData, Unit, Computel and Login). Eset in 2008 took over the company ŠetrNet (Czech Republic) and COMDOM (Slovakia). In April 2009, Soitron acquired the Czech firm ClarioNet and $51 \%$ of the Romanian company Datanet Systems. Also foreign investors joined the acquisition process. In 2008, Electronic Data Systems was taken over by HP Slovakia, and in October 2009, the PosAm Company was taken over by the Slovak Telecom (part of Deutsche Telekom).
In parallel with the boom in the industry, intense activity in the academic field has been seen. The continued pressure of companies to improve the quality of education was driving at the administrative barriers to open new and upgraded courses. As the process was rigid and slow, companies started to provide parallel training systems such as the Cisco Academy. Cooperation between firms and universities took place mostly on the basis of hosting IT professionals for lectures and seminars, supervising diploma theses and eventually organising conferences, but such cooperation was not regular. With the support of EU funds the Slovak University of Technology established a network of analytical and diagnostic laboratories, providing specific expertise (2004) and several centres of excellence (2008).

\section{Evolution of the IT sector in the Košice region}

Origins and the emergence of the IT sector (up to 2003): The IT sector was the part of the old industries before 1990. The employment in IT was situated in so-called computational centres, industrial research institutes (the leading institute was INORGA - Research Institute of Metallurgy and Heavy Engineering) and at universities. At that time, the knowledge base was directly lined up with industrial applications in the (heavy) industries of that time. Rather surprisingly from today's viewpoint, a large steel company (VSŽ) could be labelled as a vehicle of innovation processes in the region. The political and economic importance of the firm enabled it to adopt in advance, not only the newest technologies from the former socialist countries but in a limited way from western countries as well. For example, the IBM mainframe S/370in was installed in 1974, directly against the embargo of that time. This mainframe was supplemented by the new model IBM 4361 in 1986 which was in use until 2002. The disposal of the IBM technology enabled contact between informatics and IBM consultants. Also, the strategic steel company was allowed by the government to arrange the training of the software engineers of the West German firm Siemens.

Hereby the company played a dual role in the evolution of the IT industry. First, it achieved the technological advantage based on its importance. Second, it strongly influenced the regional milieu. The physical and social infrastructure was developed accordingly in the region and created the preconditions for the later foreign capital location. The regional universities - the Technical 
University of Košice and Šafárik University followed the regional development trajectories via lasting adjustments in their curricula (Automatic Control Systems and Cybernetics). Thanks to the steelworks and the national industrial policy, the IT sector before 1990 was prevalently focused on industrial applications (HuDEC/ŠEBOVÁ 2012). Also the first programming course (the FORTRAN programming language) was opened at the Faculty of Mechanical Engineering at the Technical University of Košice at the end of the 1960s. The Faculty of Electrotechnics was established later in 1969 and the number of students increased every year, becoming more and more focused on IT than electrotechnics (from 315 students in 1969 to 3055 in 2009).

The regional universities provided two kinds of IT curricula:

- Technical curriculum (at the Technical University) focused on engineering, automation and cybernetics, concentrated on hardware and related software areas,

- Mathematical curriculum (Šafárik University with a tradition of mathematical and physical science) oriented to abstract and exact reasoning and concentrated on the mathematical and theoretical basis of computer science.

The computer science development had brought several reputable research results, such as the special-purpose computer SIMUL developed at the Technical University of Košice which won awards at two international exhibitions of patents and inventions (Internemo at Cologne in 1972 and Salon International des Inventiones de Genève in 1972). The research team dealt with a multiprocessor hybrid systems based on the RPP-16 computer and the analogue computer MEDA 41. The research orientation of that team was later transformed into the development of robot control systems. The control system MUDRS was used in the robot system MYMR 50 , which was awarded the gold medal at the International Fair in Brno in 1986.

The empirical research had shown three main sources of regional knowledge before 1990, which dealt with IT research and practice. After 1990, the economic transformation to a market economy, followed by the automation of the steelworks and industrial research institutes (including INORGA), brought opportunities for individuals previously working in IT centres to start their own businesses. The third vehicle is represented by the computer engineers from the regional universities who gave birth to several important spin-offs - Elfa, Intersoft (employees from the Faculty of Electrotechnics and Informatics at the Technical University of Košice) and VSL Software (employees from the Institute of Informatics, Śafárik University). The path dependent trajectory of an IT sector adherent to the heavy and general engineering industry continued during the transition from the centrally planned to a market economy, although significantly marked by industrial decline, economic reforms and technological structural changes (ŠEBOVÁ 2009). The former hard industrial IT basis has been confronted with a new soft internetbased IT generation. The former knowledge still continues in IT service companies related to the steel industry (Rasax, Procesna automatizacia) and their managers declared in interviews low respect for the new IT generation, having no knowledge of how the real industry works. Several companies were able to adapt to the new economic conditions and to develop their own complex software applications, e.g. Telegrafia (developing warning and notification systems and related software applications), Lynx (security of information systems), ICOS (company information systems), Novitech (installation and implementation of LAN and Novell based solutions). The firms mentioned are all of medium size and considered as "old" born of the former industrial knowledge roots of the steelworks, INORGA or TESLA (electrotechnics) basis. Several regional companies were established during the period 1990-1995, focusing mostly on the administration of business IT systems and the sale of western hardware and software. The former western partners of the $V S Z \check{Z}$ also became the first foreign investors in the regional IT sector - IBM in 1990 and Siemens PSE in 1995 who established their subsidiaries in Košice, following the cooperation before 1990. One of the respondents in our research named the period 1990-2000 as the "IT Klondike". The existing firms capitalized on the advantages of the newly opened sectors with a relatively low level of competition. After filling the technological gaps, the old IT sector reached the regional market limits and the former industrial trajectory of the IT sector showed lock-in accompanied by the decrease in employment in the period 1998-2003.

Diversification and arrival of big players (post 2004): New activities not related to those already existing in the region have been driven by a combination of exogenous and endogenous factors. An incentive for reshaping the IT 
sector was the integration of Slovakia into the European Union (EU). After the year 2000 the creation of many small and micro IT firms of regional origin can be observed. Some of them were spin-offs of the European Framework Programme projects (e.g. InterSoft), but this was a period of a new generation of graduates or selfmade young men educated on computer games. The majority of the new small young IT firms are naturally connected with new programming languages, the growth of computer games, Internet and mobile technologies (HUDEC/Š́BOVÁ 2012). As an example - the young graduates elaborated on new technology (e.g. DATAcrea - game software Golf club). The orientation of IT firms has shifted gradually to web technologies and telecommunication services, following global trends. Also, the positive effects of European integration can be seen - the Lisbon Agenda started the process of e-government and the orders for the public administration stimulated IT business markedly.

The key players discovered the regional IT market as late as after the Slovak EU accession (2004). Several firms entered the region at the same time (2005-2007): Ness KDC (250 employees), RWE IT (215 employees), T-Systems (2 000 employees), IXONOS (170 employees). All of them declared their intention to increase their numbers of employees. The arrival of the T-Systems service centre has definitely changed the nature of the regional IT sector. The regional manager of T-Systems, who has created the most rapidly growing foreign subsidiary in Slovakia, grew from the computer and system department in the VSŽ steel works in the 1970s. After 1990 he managed the $I B M$ subsidiary in Košice and the Arab Emirates. The stories of other firms could affirm the crucial role of social capital in regional knowledge trajectories. T-Systems initiated the dialogue between the Triple Helix actors (universities, public administration, and firms) and supported the establishment of a regional association under the name Košice IT Valley. That was the very first clustering initiative in the region and at the same time accompanied by a publicly surprising effort to change the former metallurgical image of the Košice region for a modern IT picture.

Nowadays, the IT Valley member firms show different patterns of cooperation. Foreign firms are more involved in regional activities not connected with business (e.g. relationships with universities). But they are less interested in re- gional business cooperation and they are fairly technologically locked. Regional firms are less active in the cluster but in reality, they cooperate at the regional level although based only on the business contracts. Some regional firms have supported the establishment of another cluster initiative Biterap, more focused on the old system and automation partnership.

\section{Discussion on the path plasticity in the development of the IT sector}

The main empirical question of our research was: Why was the development of new industries in our case study regions so different? First we look at the institutions. Firms in both regions operated in the same institutional framework and faced the same institutional changes in the national economy. The common institutional changes at national level such as the economic transformation towards a market economy (privatization, liberalisation of the price system and trade), entry to the EU (free mobility of capital and the adoption of the institutional framework of EU members) and economic reforms (tax system, upgrade of the business environment, and flexibility of labour market) between 2002 and 2006 resulted in different development paths in the regions. Both regions faced the legacy of a national innovation system inherited from the planned economy which was dominated by applied research for the large manufacturing sector. This situation impeded the development of an emerging IT sector within the established path of industrial IT solutions. The knowledge accumulation of the future emerging sector had started a long time before the first IT firms emerged. Competencies were developed within the parent sector and academia. The radical institutional changes in the economy associated with the transition from central planning to a market economy represented a common trigger for the evolution of the IT companies in both regions. The emergence of a new industry is not accidental or serendipitous, but it is historically framed by the existing institutions. The evolution, however, has shown an obvious path dependent development of the IT sector in the Košice region and the more dynamic and plastic development of the sector in the Bratislava region.

The opening of the economy in the 1990s brought much higher foreign investments in the IT sector in the Bratislava region compared to Košice. Bratislava was attractive in terms of its 
location and the size of the market, the presence of state institutions, financial institutions and headquarters of large companies. The inflow of foreign investment in the Košice region was the result of previous collaborations with major local companies from the period before 1989. Therefore, the same institutional change resulted in a different impact on the development of the sector in both regions. It resulted in higher diversification in the Bratislava region but deepened the path dependency and specialization in the Košice region. Further institutional changes related to Slovakia's accession to the EU and later the introduction of the Euro, brought additional incentives for the further expansion of foreign investment in Slovakia (ŠIPIKAL 2010). It is interesting that we have observed the relocation of some of the IT companies from Bratislava to Košice since the year 2000. It was mainly because of cost arguments, as the wages in the Košice region were almost half those in the Bratislava region. But the process was also supported by local government and universities which put more effort into the reconstruction of their education system. The whole process resulted in the cluster initiative IT Valley in 2007, which aimed to change the industrial image of the Košice region towards a more modern IT image, showing a desire and a will to escape the established path of the past. Similar to the study of TöDtLing et al. (2011) on the IT sector in the
Moravia Silesia (Czech Republic), transformed economies are, despite investments in the regional innovation system, still typical for the low level of cooperation compared with other western economies.

The economic reforms of the years 2002 to 2004 were aimed at increasing the flexibility of the labour market (the removal of barriers to hiring and firing workers). Similar to the STRAMBACH (2010) study on customized business software in Germany, flexibility of the labour market is a key element for the development of the IT sector. The IT sector is typical for part-time jobs, freelancing and personal leasing. Thus institutional changes not only helped the growth of the industry but also allowed greater labour mobility, which brought higher spillovers to the industry.

A greater plasticity in the industry development in the Bratislava region could be observed also in the formation of associations in the field of information technology. The emergence of associations in the Bratislava region appeared much sooner, it is much richer and shows substantially greater dynamics compared with the Košice region. The establishment of more specialized associations (IT security, e-commerce, system integration ...) in Bratislava signals the on-going process of institutionalization of new subsectors.

Tab. 1: Comparison of IT sector development in the Bratislava and Košice regions

\begin{tabular}{|c|c|c|c|c|}
\hline & \multicolumn{2}{|c|}{$1990-2004$} & \multicolumn{2}{|c|}{$2004-2011$} \\
\hline & Bratislava region & Košice region & Bratislava region & Košice region \\
\hline $\begin{array}{l}\text { Markets/ } \\
\text { Demand }\end{array}$ & $\begin{array}{l}\text { National and partly } \\
\text { international }\end{array}$ & Mainly local & Increasingly global & $\begin{array}{l}\text { National and inter- } \\
\text { national }\end{array}$ \\
\hline Focus & $\begin{array}{l}\text { Industrial applications } \\
\text { with substantial increase } \\
\text { of IT services }\end{array}$ & $\begin{array}{l}\text { Mainly industrial } \\
\text { applications }\end{array}$ & $\begin{array}{l}\text { IT services for finance, te- } \\
\text { lecommunications, public } \\
\text { administration (system in- } \\
\text { tegration, data processing, } \\
\text { outsourcing ...), IT secu- } \\
\text { rity, mobile solutions ... }\end{array}$ & $\begin{array}{l}\text { Industrial applications, } \\
\text { raise of IT services } \\
\text { (outsourcing, informa- } \\
\text { tion systems) }\end{array}$ \\
\hline
\end{tabular}

\begin{tabular}{|c|c|c|c|c|}
\hline$M N E$ & Several & Few & Many & Several \\
\hline Universities & $\begin{array}{l}\text { Balanced generic and } \\
\text { applied IT education }\end{array}$ & $\begin{array}{l}\text { Applied IT } \\
\text { education }\end{array}$ & $\begin{array}{l}\text { Balanced generic and ap- } \\
\text { plied IT education }\end{array}$ & $\begin{array}{l}\text { Balanced generic and } \\
\text { applied IT education }\end{array}$ \\
\hline Associations & $\begin{array}{l}\text { Emerging (mainly in se- } \\
\text { cond half of the period) }\end{array}$ & Non existing & Fully established & $\begin{array}{l}\text { First cluster initiative } \\
\text { in } 2007\end{array}$ \\
\hline $\begin{array}{l}\text { Knowledge } \\
\text { dynamics }\end{array}$ & $\begin{array}{l}\text { Cumulative and com- } \\
\text { binatorial }\end{array}$ & Cumulative & Combinatorial & $\begin{array}{l}\text { Cumulative and increa- } \\
\text { singly combinatorial }\end{array}$ \\
\hline Path & $\begin{array}{l}\text { From dependency to } \\
\text { plasticity }\end{array}$ & Path dependency & Path plasticity & $\begin{array}{l}\text { From dependency to } \\
\text { plasticity }\end{array}$ \\
\hline
\end{tabular}


Another important finding was that the firms which had introduced successful innovation had entirely internal innovation processes without any formal cooperation with local firms or universities. It means that firms are trying to escape from the established institutional system in order to develop their own system of routines.

Our studies have shown that one of the main factors that influenced the distinct development of sectors in the case study regions was the structure and dynamics of demand. The development of IT products is frequently based on a project form of organisation, which requires close interaction with clients. Currently the knowledge generation in the IT sector is carried out by a complex application process and we have observed a shift from the specialisation of one knowledge domain towards combinatorial knowledge dynamics (STRAMBACH 2008). The dominant feature of the IT sector is its dynamic interconnection with other sector contexts. Knowledge generation is based on a complex mixture of horizontal (technology knowledge) and vertical knowledge domains (different markets, industrial knowledge). Over time not only do firms develop technology competencies but also competences which are related to the specific markets which they serve.

Several IT firms detached from their parent companies in a dominant sector in the region. These were mainly large manufacturing firms in the chemical industry (Slovnaft, Istrochem) and automotive engineering $(B A Z)$ in the Bratislava region or the metallurgical industry (VSŽ) in the Košice region. Therefore, a common denominator of the IT sector knowledge base development in both regions was a significant effect of pre-existing dominant regional industries. This reflects the notion of knowledge inheritance between parent and progeny organisations (AGARWAL et al. 2004) and the crucial role of the founders, who acquired knowledge and developed routines while working in the incumbent firm. Large manufacturing firms in a dominant sector were the main customers of IT companies; therefore industry applications, such as control and information systems, were the main IT products at that time. Firms in the Bratislava region quickly expanded their markets into other areas, especially into finance, network industries, public administration, and benefited from the proximity of the clients in the region. In addition, they expanded their services to the whole country and also abroad. Manufacturing comprises currently only $19 \%$ of the IT market in Slovakia, whereas telecommunications and transportation $25 \%$; finance $15 \%$, and public administration $15 \%$. During the same period the IT firms in the Košice region focused on the industrial IT applications for large local manufacturing firms which were their stable customers. Knowledge in the Košice region was generated in a cumulative way and firms were further deepening their specialization within the established path. The case from the Košice region indicates that when the provision of IT services closely focuses on one sector, that sector may experience lock-in problems.

Even given that local agents (universities, customers and competitors) are an important source of knowledge for innovation in the IT sector, firms also benefit from external inputs of knowledge to gain access to the knowledge that is not available locally (TRIPPLE et al. 2009). There was a significant breakthrough towards distant knowledge interactions in the second phase in both regions. Companies entered non-local and foreign markets by opening branches and merging and taking over foreign companies. These changes were related to the entry of Slovakia into the EU and opening larger markets. Local branches of MNEs currently serve Europe, the Middle East and Africa and markets from Bratislava and Košice. Knowledge dynamics within the MNEs is based on the distance knowledge interactions, thus far with limited local inter-firm learning. Large multinational firms have created internal channels through which they are able to transfer non-local knowledge. They have established specialised departments serving local and distant markets and have also developed specific mechanisms for transferring the best practices from other localities. As consultancy is dominated by tacit/sticky knowledge with a level of the embodiment co-operation activities, specialised training in competence centres is in rotation between offices. The invitation and/or recruitment of experts are crucial forms of such a knowledge anchoring mechanism.

Finally, the last distinctive feature of the development of the IT sector in the Bratislava and Košice regions was the university system. There is a close relationship between the educational system and the development of industry. The IT sector is characterized by a synthetic knowledge base (CoOKe/De LAurentis 2007) and especially in the Košice region; IT courses at the local universities were focused on industrial IT applications at the University of Technology 
in Košice. IT education in the Bratislava region was more generic and equally focused on analytical knowledge (Faculty of Mathematics, Physics and Informatics at Comenius University) and synthetic knowledge (Faculty of Informatics and Information Technologies at the Slovak University of Technology). The pressure of big companies and associations lead to the reform of the educational system. Curricula are gradually changing according to societal changes, economic and market requirements. The whole process is slow and rigid and there is a shortage of qualified employees on the market.

Universities played a greater role in the development of the IT sector in the Bratislava region as the education sector was more than twice as large as that in Košice. The collapse of the academic sector in the 1990s was associated with the growth of new business opportunities. A similar stimulus has been the simplification of entrepreneurship since 2000, both factors stimulating the academics to establish their own businesses. Part of the IT industry in the Bratislava region has its origin in the academic sector, which was much more diversified compared to the highly specialized system in the Košice region. Therefore, universities have contributed to the path plasticity in the Bratislava region; nonetheless, they supported the path dependency in the Košice region.

\section{Conclusions}

The emergence of new industries should not be viewed in isolation from the economic, social and institutional contexts. Both aspects may strengthen path dependency and lock-in or to allow plasticity of the path. Unlike the deterministic approach within the path dependency concept, the concept of path plasticity examines the extent to which development can deviate from the previous path without collapsing the established institutional system. This article contributes to the debate on the development of new industries from the perspective of evolutionary economic geography exploring the relationship between path dependency and path plasticity. The research into the development of the IT sectors in the Bratislava and Košice regions has an exploratory character focused on the factors promoting plasticity in the evolution of the IT sector. The IT sectors in the two regions started under similar conditions, they tackled the same institutional changes, and despite this, their progress has been rather dissimilar.
The case studies have shown that the roots of the new regional industries are much deeper than it appears at first sight. The knowledge pools are cumulated a long time before the first firms of the emerging industries appear. The factor of the transition from the centrally planned to a market economy has brought extensive entrepreneurial opportunities for the IT sector. The required knowledge has been inherited mainly from the firms in dominant regional industries and partly from the universities. The rate at which the new sector remained tied to the parent industry explains a great part of the story. The innovation system inherited from the planned economy was based on industrial applications and synthetic knowledge generation remained dominant for much longer in the Košice region. The path dependency development prevailed because of the reliance on large local (manufacturing industry), technical curricula in the education system and a lack of foreign investment. All these factors combined and resulted in cumulative knowledge dynamics and path dependency. On the other hand, greater diversity of demand, inflow of multinational enterprises and a much larger variety of IT education in the Bratislava region resulted in combinatorial knowledge dynamics and led to path plasticity.

\section{Acknowledgements}

This paper was supported by the Slovak Research and Development Agency based on the contract APVV-0230-07 and the EURODITE project "Regional Trajectories to the Knowledge Economy: A Dynamic Model" supported by the EU Sixth Framework Program, Priority 7: Citizens and Governance in a Knowledge-based Society, Proposal/ Contract No. 006187, Integrated Project (2005-2010). The authors would like to thank the teams of EURODITE and REDIPE projects. Also we would like to acknowledge support and engagement with the field research of Rudolf Pastor, Martin Chovanec and Miriam Šebová.

\section{Notes}

1 We use the term IT sector for firms in software programming, IT services (system integration, outsourcing, web services) and data processing.

2 EURODITE project "Regional Trajectories to the Knowledge Economy: A Dynamic Mode" supported by the EU Sixth Framework Program, Priority 7: Citizens and Governance in a Knowledge-based Society, Proposal/ Contract No. 006187, Integrated Project (2005-2010). Project REDIPE (Regionálne dimenzie poznatkovej ekonomiky) "Regional Dimensions of Knowledge Economy" was supported by the Slovak Research and Development Agency based on the contract APVV-0230-07 (2009-2011). 


\section{References}

Agarwal, R. / Echambadi, R. / Franco, A. M. / SARKar, M. B. (2004): Knowledge transfer through inheritance: Spinout generation, development and survival. In: Academy of Management Journal, (47)4, 501-522.

ANTONELLI, C. (2008): Localised technological change. Towards the economics of complexity. Oxon.

ARTHuR, B. (1994): Increasing returns and path dependence in the economy. Ann Arbor.

Asheim, B. / Coenen, L. / Moodysson, J. / VAnG, J. (2007): Constructing knowledge-based regional advantage. Implications for regional innovation policy. In: International Journal of Entrepreneurship and Innovation Management, (7)2-5, 140-157.

Bathelt, H. / Malmberg, P. / Maskell, P. (2004): Clusters and knowledge. Local buzz, global pipelines and the process of knowledge creation. In: Progress in Human Geography, (28)1, 31-56.

Boschma R. / Frenken, K. (2011): The emerging empirics of evolutionary economic geography. In: Journal of Economic Geography, (11)2, 295-307.

Boschma, R./VAn der KnaAP, G.A. (1999): New hightech industries and windows of locational opportunity. The role of labour markets and knowledge institutions during the industrial era. In: Geografiska Annaler: Series B, Human Geography, (81)2, 73-89.

Boschma, R. / Frenken, K. (2006): Why is economic geography not an evolutionary science? Towards an evolutionary economic geography. In: Journal of Economic Geography, (6)3, 273-302.

Boschma, R. / Wenting, R. (2007): The spatial evolution of the British automobile industry. Does location matter? In: Industrial and Corporate Change, (16)2, 213-238.

BraczyK, H.-J. / COOKE, P. / HeIdENREICH, M. (Eds.) (1998): Regional innovation systems. London.

Buenstorf, G. / Klepper, S. (2009): Heritage and agglomeration: The Akron tyre cluster revisited. In: The Economic Journal, (119)537, 705-733.

CAmagni, R. / Maillat, D. (Eds.) (2006): Milieux innovateurs: Théorie et politiques. Paris.

Cohen, W. M./Levinthal, D.A. (1990): Absorptive capacity: A new perspective on learning and innovation. In: Administrative Science Quarterly, 35, 128-152.

Cooke, P. / De Laurentis, C. (2007): Trends and drivers of the knowledge economy in seven business sectors. Cardiff. (Centre for Advanced Studies, Cardiff University, WP3 Summary Report, EURODITE).

Crevoisier, O./Jeannerat, H. (2009): Territorial knowledge dynamics. From the proximity paradigm to multilocation milieus. In: European Planning Studies, (17)8, 1223-1241.

DAHL, M. S. / ØstergaARD, C. R. / DAlum, B. (2011): Emergence of regional clusters. The role of spin-offs in early growth process. In: Boschma, R. / Martin, R. (Eds.) (2011): The Handbook of Evolutionary Economic Geography. Cheltenham.
DAHLSTRÖM, M./JAMES, L. (2012): Regional policies for knowledge anchoring in European regions. In: European Planning Studies, (20)11, 1867-1887.

DAVID, P. (1985): Clio and the economics of QWERTY. In: The American Economic Review, (75)2, 332-337. (Papers and Proceedings of the Ninety-Seventh Annual Meeting of the American Economic Association May 1985).

DYKeR, D.A. (1997): Learning the game. Technological factors of economic transformation, In: Europe-Asia Studies, (49)3, 445-461.

DYKer, D.A./RADOŠEvić, S. (2000): Building the knowledge-based economy in countries in transition. From concepts to policies. In: Journal of Interdisciplinary Economics, (12) 1, 41-70.

FAUlCONBRidge, J.R. (2006): Stretching tacit knowledge beyond a local fix? Global spaces of learning in advertising professional service firms. In: Journal of Economic Geography, (6)4, 517-540. doi: 10.1093/jeg/lbi023.

FLORIDA, R. (1995): Towards the learning region. In: Futures, (27) 5, 527-536.

Frenken, K. / VAn OORT, F. G. / VerburG, T. (2007): Related variety, unrelated variety and regional economic growth. In: Regional Studies, (41)5, 685-697.

Garud, R. / Karnøe, P. (2001): Path creation as a process of mindful deviation. In: Garud, R. / Karnøe, P. (Eds.): Path dependency and creation. Mahwah, 1-38.

Grabher, G. (1993): The weakness of strong ties. The lockin of regional development in the Ruhr area. In: Grabher, G. (Ed.): The embedded firm. On the socioeconomics of industrial networks. London/ New York, 255-277.

Hodson, M. (2008): Old industrial regions, technology, and innovations. Tensions of obduracy and transformation. In: Environment and Planning, 40, 1057-1075.

Hudec, O. / Š́bovÁ, M. (2012): The ICT sector evolution in an industrial region of Slovakia. In: Ekonomický časopis, 1, 65-82.

Hudson, R. (2005): Rethinking change in old industrial regions. Reflecting on the experiences of North East England. In: Environment and Planning, (37)4, 581-596.

KLEPPER, S. (2002a): The evolution of the U.S. automobile industry and Detroit as its capital. Gainesville. (Paper presented at 9th Congress of the International Joseph A. Schumpeter Society, Gainesville, Florida, March 2002).

KLEPPER, S. (2002b): The capabilities of new firms and the evolution of the US automotive industry. In: Industrial and Corporate Change, (11)4, 645-666.

KLEPPER, S. (2010): The origin and growth of industry clusters. The making of Silicon Valley and Detroit. In: Journal of Urban Economics, 67, 15-32.

Krugman, P. (1991): History versus expectations. In: The Quarterly Journal of Economics, (106)2, 651-667.

MAninche, J. (2012): Combinatorial knowledge dynamics. On the usefulness of the differentiated knowledge bases model. In: European Planning Studies, (20)11, 1823-1841.

Martin, R. / Simmie, J. (2008): Path dependence and local innovation systems in city regions. In: Innovation, Management, Policy and Practice, (10), 183-196. 
Martin, R. / Sunley, P. (2006): Path dependence and regional economic evolution. In: Journal of Economic Geography, (6)4, 395-437.

Morgan, K. (1997): The learning region. Institutions, innovation and regional renewal. In: Regional Studies, (31)5, 491-503.

Moulaert, F. / Sekia, F. (2003): Territorial innovation models. A critical survey. In: Regional Studies, (37)3, 289-302.

NoRTH, D. (2003): Economic performance through time. The limits to knowledge. In: The American Economic Review, (84)3, 359-368.

NoRTH, D. (1990): Institutions, institutional change, and economic performance. New York.

PÁsTOR, R. (2012): Znalosti a inovácie v sektore informačno-komunikačných technológií. In: Ekonomický časopis, (60)10, 1024-1040.

PIECH, K. (2007): Knowledge and innovation processes in Central and Eastern Europe. Warsaw. (The Knowledge \& Innovation Institute).

Piore, M. / Sabel, M. (1984): The second industrial divide. Possibilities for prosperity. New York.

PORTER, M.E. (1990): The competitive advantage of nations. New York.

SAXenian, A.L. (1994): Regional advantage. Culture and competition in Silicon Valley and Route 128. Cambridge, MA.

SCOTT, A. J. / Storper, M. (1987): High technology industry and regional development. A theoretical critique and reconstruction. In: International Social Science Journal, (39), 215-322.

Sorenson, O. / Rivkin, J. W. / Fleming, L. (2006): Complexity, networks and knowledge flow. In: Research Policy, (35)7, 994-1017.

Sotarauta, M. / Ramstedt-SEN, T. / Seppänen, S. K. / KoSONEN, K.-J. (2011): Local or digital buzz, global or national pipelines: Patterns of knowledge sourcing in intelligent machinery and digital content services in Finland. In: European Planning Studies, (19)7, 1305-1330.

STORZ, C. (2008): Innovation, institutions and entrepreneurs. The case of 'Cool Japan'. In: Asia Pacific Business Review, (14)3, 401-424.

StRAmbach, S. (2008): Knowledge-intensive business services (KIBS) as drivers of multilevel knowledge dynamics.
In: International Journal of Services Technology and Management, (10)2-3-4, 152-174.

Strambach, S. (2010): Path dependency and path plasticity. The co-evolution of institutions and innovation. The German customized business software industry. In: Boschma, R.A. / Martin, R. (Eds.): Handbook of Evolutionary Economic Geography. Cheltenham, 406-431.

Strambach, S. / Klement, B. (2012): Cumulative and combinatorial micro-dynamics of knowledge. The role of space and place in knowledge integration. In: European Planning Studies, (20)11, 1843-1866.

Suire, R. / VicENTE, J. (2009): Why do some places succeed when others decline? A social interaction model of cluster viability. In: Journal of Economic Geography, (9)3, 381-404.

ŠEBovÁ, M. (2009): The role of the institutional thickness in the knowledge processes of the old industrial regions. In: Region Direct, (2)1, 130-151.

ŠIPIKAL, M. (2010): Priame zahraničné investície v ekonomike Slovenska. In: Wokoun, R. / Tvrdoň, J. (Eds.): Přímé zahraniční investice a regionální rozvoj. Praha, 47-64. (Vysoká škola ekonomická v Praze. Nakladatelství Oeconomica).

Tödtling, F. / Skokan, K. / Höglinger, C. / Rumpel, P. / GRILLITSCH, M. (2011): Innovation and knowledge sourcing of modern sectors in old industrial regions. Comparing software firms in Moravia-Silesia and Upper Austria. In: European Urban and Regional Studies. doi: $10.1177 / 0969776411428498$.

TRIPPL, M. / TöDTLing, F. (2008): Cluster renewal in old industrial regions. Continuity or radical change? In: Karlson, C. (Ed.): Handbook of Research on Cluster Theory. Cheltenham, 203-218.

Trippl, M. / TÖDtling, F. / Lengauer, L. (2009): Knowledge sourcing beyond buzz and pipelines. Evidence from the Vienna software sector. In: Economic Geography, (85)4, 443-462.

Vale, M. / CARVAlho, L. (2012): Knowledge networks and processes of anchoring in Portuguese biotechnology. In: Regional Studies. doi:10.1080/00343404.2011.644237.

VicEnTE, J./ Suire, R. (2007): Informational cascades versus network externalities in locational choice. Evidence of 'IT clusters' formation and stability. In: Regional Studies, $41,1-12$. 


\section{Appendix: List of interviews}

\begin{tabular}{|c|c|c|c|}
\hline & Type of institution & Institution & Date \\
\hline 1. & Association & Slovenská informatická spoločnost, Bratislava & May 2010 \\
\hline 2. & Association & ITAS, Bratislava & May 2010 \\
\hline 3. & Innovation Centre & BIC Bratislava, Bratislava & June 2010 \\
\hline 4. & University & $\begin{array}{l}\text { Faculty of Informatics and Information Technologies, } \\
\text { SUT Bratislava }\end{array}$ & July 2010 \\
\hline 5. & University & Faculty of Electronics and Informatics, SUT Bratislava & July 2010 \\
\hline 6. & Company & Gratex International, Bratislava & July 2010 \\
\hline 7. & Company & Soitron, Bratislava & June 2010 \\
\hline 8. & Company & Asseco Solutions, Bratislava & June 2010 \\
\hline 9. & Company & Slovakodata, Bratislava & June 2010 \\
\hline 10. & Company & PosAm, Bratislava & July 2010 \\
\hline 11. & Company & mSolutions, Bratislava & July 2010 \\
\hline 12. & Company & $H P$, Bratislava & July 2010 \\
\hline 13. & Company & Eset, Bratislava & September 2009 \\
\hline 14. & Company & Pixel Federation, Bratislava & October 2009 \\
\hline 15. & Company & AlfaBase, Bratislava & October 2009 \\
\hline 16. & Company & Softec, Bratislava & October 2009 \\
\hline 17. & Company & Creas, Bratislava & October 2009 \\
\hline 18. & Company & $A C E$, Bratislava & November 2009 \\
\hline 19. & Company & P-Mat, Bratislava & November 2009 \\
\hline 20. & Company & Razuta, Bratislava & November 2009 \\
\hline 21. & University & Šafarik University, Department of Computer Science, Košice & April 2010 \\
\hline 22. & Cluster/association & Košice IT Valley, Košice & April 2010 \\
\hline 23. & Regional administration & ICT Department, Košice & April 2010 \\
\hline 24. & City administration & Infrastructure Department, Košice & April 2010 \\
\hline 25. & Regional administration & Regional Development Department, Košice & May 2010 \\
\hline 26. & Company & T-Systems, Košice & April 2010 \\
\hline 27. & Company & Siemens Program and System Engineering s.r. o., Košice & May 2010 \\
\hline 28. & Company & Procesná automatizácia, Košice & April 2010 \\
\hline 29. & Company & ICOS, a.s. Košice, Košice & May 2010 \\
\hline & Company & RWE IT Slovakia, s.r.o., Košice & May 2010 \\
\hline 31. & Company & NESS KDC, s.r.o., Košice & April 2010 \\
\hline & Company & Novitech, a.s., Košice & May 2010 \\
\hline & Company & InterSoft, a. s., Košice & May 2010 \\
\hline 34. & Company & IXONOS, s.r.o., Košice & April 2010 \\
\hline & Company & ELFA, s.r.o., Košice & May 2010 \\
\hline & Company & VSL Software, a.s., Košice & May 2010 \\
\hline & Company & Telegrafia, a.s., Košice & May 2010 \\
\hline & Company & Lynx, s.r.o., Košice & April 2010 \\
\hline 39. & Company & $A P E X$, a.s., Košice & May 2010 \\
\hline & Company & RASAX, a.s., Košice & May 2010 \\
\hline
\end{tabular}

